\title{
The Effects of Occupational Licensing on Skills Needs in the Building Industry: Evidence from New Zealand
}

Yadeed B Lobo (Department of Civl and Environmental gineerin. University of uck

New zealand) and Suzanne Wilkinson (Department of C1v1land Environmental Engmeenng, Umvers1ty of Auckland, Auckland, New Zealand)

\section{ABSTRACT}

Occupationallicensing for the building industry is being introduced in New Zealand. This research assesses whether the licensing regime being put into place in New Zealand would require new skills when voluntary licensing (2007) and compulsory licensing (by 2011) are introduced. The paper develops a deeper understanding of the effects of occupational licensing on an industry, above those of increased quality and training, to determine the effects of licensing on future skills needs in the New Zealand building industry. The results of the in-depth interviews of 35 leading practitioners in the New Zealand show how occupationallicensing will affect skills in the industry in two main ways: increase professionalism and increased specializa ioin skills. The impact on the New Zealand bu1ld1ng industry will be to force a change in the working practices, increasing the move to offsite . prefabrication and change the types of sk1lls the industry requires. The paper serves as an illustration to other countries on how changes in legislation, and the introduction of regulation for an industry, alter the working practices of that industry.

Keywords: Skills, Building Industry, Occupational Licensing, New Zealand

\section{INTRODUCTION}

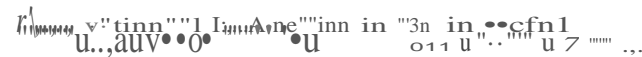
common way for governments to exert control over professions, whilst promoting quality goods and services. The main objective of this research was to assess whether the licensing regime being put into place in New Zealand would require new skills when voluntary licensing (2007) and compulsory licensing (by 2011) were introduced. In this paper, an overhaul of the New Zealand building industry with respect to the introduction of occupational licensing is discussed. The paper develops a deeper understanding of the effects of occupational licensing on an industry, above those of increased quality and training, to determine the effects of licensing on future skills needs in the New Zealand building industry. First the definition of the term occupationallicensing is presented. Then its effects on skills and skills shortages are analysed. New licensing regimes in the New Zealand building industry are reviewed and the potential impacts of these regimes are discussed from the perspective.of top industry players in government, compan1es and industry training organisations. The paper serves as an illustration of how central government control through licensing impacts on the lives of all building participants and consumers in both positive and negative ways. The paper also shows how the introduction of licensing can change the landscape of an industry.

\section{OCCUPATIONAL LICENSING IN THE BUILDING INDUSTRY AND ITS EFFECTS}

Licensing is seen as state regulation that protects the public from the incompetent or unscrupulous practitioner, but it could also be understood to be used by occupational groups to restrict entry at the expense of public interest (Zhou, 1993). The definition of licensing i the context of regulation of the labour market 1s defined in Arkani et al(Arkani et d, 2003) as

"...a set of rules embedded in a structured institutional framework, whether at local or state level that determine, orchestrate or bind reiationships between capiiai and iabour prevailing in a teffitoryn. Kleiner (Kleiner, 2000) and Arkani et al. (Arkaniet d, 2003) both point out that occupational licensing is a set of rules by government which restricts entry to a profession through some demonstration of a minimum degree of competency. This is usually done through a licensing board who manage the licensing process, including fees and registration, and sets the entry requirements 
(Kleiner, 2000). Significantly, in a licensed occupation it is illegal to practice without a license.

Studies indicate that licensing causes not only wages to increase but also restricts the current number of practitioners leading to skills shortages (Carrol and Gaston, 1983; Kleiner. 2000). Authors who have studied licensing agree that the main effect of licensing is improved quality of service provided for the consumer (Carrol and Gaston, 1983; Kleiner, 2000). The quality of the work or service will increase as less competent individuals are prevented from entering the occupation. In terms of quality, Carroll and Gaston (Carroll and Gaston, 1983) argue that more stringent restrictions deliver higher quality of service. In addition to improved quality, another advantage of licensing is better training as licensing imposes minimum competencies on a person in that occupation, which almost always need to be met by training. Better training also has an impact on quality as the trained person can provide a reasonable guarantee of the skill level of work undertaken (Kleiner. 2000).

The main disadvantage of licensing is increasing wages (Perloff, 1980; Carroland Gaston 1983, Kleiner, 2000). Increased costs arise from the increase in the cost of labour as well as that of the associated services (Rottenberg, 1980). Licensing an occupation in terms of entry-level restrictions causes the supply of labour to the occupation to become restricted. It can reduce the number of new entrants to the occupation as individuals consider the cost of entering an occupation and passing/failing exams (Rottenberg, 1980). Licensing can also restrict movement of labour between industries as different licensing regimes tend to preclude transfer or restrict movement between industries (Perloff, 1980).

A recent example of builder licensing is found in Victoria, Australia. This system was introduced for licensing of building practitioners (Georgiou et al.. 1999). With the exception of architects. who had their own Registration Act, most practitioners were required to be registered (Georgiou et al., 1999). The system was created primarily for the housing section of the market. (Georgiou, 2000; Building Control Commission, 2003). Georgiou (Georgiou, 2000) outlines licenses for 3 classes of domestic building work: domestic building work (unlimited license). domestic building work (limited license) and domestic building work (managers' license). The system does not seek to impose Iicensing on all skills within the industry (Building Control Commission, 2003). The licensing system has in place a system of competencies to be satisfied for registration, which have to be assessed. Rather than describing the skills which the individual should possess the discussion papers (Building Control Commission, 2005) revealthat knowledge and the ability to do work are used. More specifically the competencies are defined in groups of work practice, professional practice, construction technology and legislation. Each of these groups has defined within itself the specific tasks, which a person who is licensed as a practitioner in that category is required to be able to accomplish. Building practitioners usually have to be trade or tertiary qualified with some exceptions of training through certificate courses (Georgiou, 2000). This system is markedly different from that proposed in New Zealand.

\section{THE NEW ZEALAND LICENSING REGIME}

In New Zealand the Built Environment Research Agenda of the Construction Industry Council's Construction Liaison Group estimates that the built environment is New Zealand's biggest physical asset with a value of $\$ 275$ billion, and added to at the rate of $\$ 11$ billion a year (CIC, 2005). There are currently few entry-level restrictions imposed by government in the New Zealand building industry. Engineering and architecture have restrictive entry provisions in the form of professional registration requirements and at the trades level, plumbing, gas fitting and electricians also have registration boards. The failure of the building industry in the recent past (Hunn et al., 2002) in part caused the government to overhaul the Building Act (Building Act, 2004) and introduce the licensing of building practitioners. Thus regulation of the industry in terms of licensing of skills is to be implemented; specifically, voluntary licensing in 2007 and compulsory licensing between 2009 and 2011 (DoBH, 2005). The New Zealand Department of Building and Housing estimates that a minimum of 25,000 people will seek licensing of which 22,000 will require to be assessed and nearly 11,000 will require some degree of upskilling (DoBH, 2005a). However, New Zealand is facing a current skills shortage, and concerns have been expressed about the introduction of such a licensing regime at times of employee shortages (NZIER, 2004). Staff shortages in building are higher than in the other sectors (NZIER, 2004a). In 2005, a shortage of staff was holding back expansion for over $70 \%$ of 
building industry finns (NZIER, 2005). For skilled construction worker vacancies advertised in May 2004 the average vacancy fill rate was 35\% (Dol,2004), a fill rate lower than $80 \%$ is indicative of a shortage and lower than $40 \%$ of an acute shortage (Do, 2006). The most severe need was for bricklayers. The Labour Cost Index (Do, 12005) has recorded a wage rate increase of 4.3 percent for the construction industry between September 2004 and September 2005, the highest for any industry in the past year.

A number of different questions can be raised about the effects of licensing on future skills. Will licensing have an effect on skills in the building industry? Will skills shortages be further exacerbated due to licensing? Will licensing lead to a change in direction in skills? Skills shortages and occupationallicensing are being specifically used to account for Osborne and Bell's (2005) observation that future skills needs analysis in OECD countries should take into account medium to long tenn variations occurring in occupational classifications in the context of changes taking place in the economy.

The residential sector of the building industry in New Zealand failed the consumer in the recent past. Specifically an investigation (Hunn et al., 2002) into the weather tightness issue in the New Zealand building industry was sceptical about the quality of service provided on site and made a list of recommendations to be implemented. Recommendation 16 was concerned with the skills of practitioners. It stated (Hunn et al., 2002) "That the BIA (Building Industry Authority) in conjunction with the appropriate affected sector groups: a) Explore the issues involved in advocating the national registration of builders and building related trades, given the contents of this report and concerns expressed about the standards of some trade practices on-site; and b) support such advocacy if it is convinced of the benefits to the Industry".

Whiie the iicensing of trades in the foffli of Accredited Building Practitioners was suggested, the report (Hunn et al., 2002) envisaged a system wherein differing levels of responsibility had different licences. This report influenced the government to legislate the Licensing of Building Practitioners under Part 4 of the Building Act 2004 (Building Act, 2004). The Ministry of Economic Development (MED, 2003) recommended a mandatory licensing regime. Only restricted work, work critical to the integrity of the structure of a building, would be required to be done by a licensed building practitioner. Restricted work (DoBH, 2004) would be work that requires a consent, is structural or part of the building envelope, and represents a significant risk to health and safety if not done properly. As of July 2005, restricted work for the purpose of reference of licensing practitioners involved (DoBH, 2005b) foundations, structural framing, cladding, external doors and windows, and roofing. As of July 2006, three types of building projects would require licensed building practitioners (DoBH, 2006a):

1. Construction of new buildings for occupation as workplaces or places of residence.

2. Projects to change the use of a building (e.g, from an office to an apartment).

3. Major alterations or extensions to an existing occupied building (e.g. adding a bedroom or an extra floor).

The Building Act (Building Act, 2004) also made provision for the consolidation of the different arms of the government dealing with the building industry. As a result of this the New Zealand Department of Building and Housing was established in 2004 . Licences for practitioners would be granted by the Registrar of Licensed Building Practitioners who would be employed by the Department. A Building Practitioners Board was designated within the Department be in charge of setting license standards. The final license classes after the consultation process were:

- Three building design licences and three building site supervisor licences based on building complexity.

- Seven specialist licence classes across all categories of building complexity (3 specialist building licences, which apply across all building categories were concrete structure, steel structure and building services and 4 trade licenses were carpentry, external plaster systems, roofing, brick and block laying) $(\mathrm{DoBH}$, 2005b). The DBH document (DoBH, 2005) proposes the establishment of these specialist and trade licenses using the justification that the site supervisor would not be competent in all these areas and hence a specialist license class sign off is necessary. For instance, the Department of Building and Housing state that, for roofers, "It is likely that many Licensed 
Building Practitioners holding a specialist licence are competent only for a subset of work within that licence class. For example, there are five major roofing types and practitioners tend to specialise and be fully trained in one or two roofing types, rather than all of them. Similar situations may arise in the other specialist licence classes" (DoBH, 2005b).

The timetable for implementation proposed is: (DoBH, 2005) Systems/Processes in place for licensing, assessment and training provision end of 2006, Voluntary licensing begins 2007, Licensing of compulsory restricted work by 2011 .

The potential impacts of licensing in the New Zealand building industry are not well understood. The general effects such as increased quality and higher labour costs have been considered, but what is not understood is the effects this licensing regime will have on future skills needs in the building industry. Would, for instance, the changes lead to increased specialisation or increased generalisation? The Ministry of Economic Development (MED, 2003a) believed that the proposed licensing regime would result in barriers to entry for building practitioners with the requirements of, and cost of, registration being the key influencing factor in the New Zealand context. The positive impact detailed by the report (MED, 2003a) was that it would lead to an increase in skill I evels in the industry.

\section{RESEARCH METHODOLOGY}

The main objective of this research was to assess whether the licensing regime being put into place in New Zealand would require new skills when voluntary licensing (2007) and compulsory licensing (by 2011) were introduced. The way in which this research objective was achieved was a mix of qualitative and quantitative research. Grounded theory technique identified by Glaser and Strauss (Glaser and Strauss, 1967) and Glaser (Glaser, 1992) was used in the research. This type of research has an emergent methodology where the side-by-side comparison of theory emerging from the collected data is used to understand the research problem. Data was used to identify, understand and compare issues, which were of relevance to the main research objective.
The fieldwork research method adopted was semistructured interviews. The mode of interviewing was semistructured as the participants had the freedom to discuss issues, which were not included in a particular question, and also the researcher was permitted to probe into certain topics, which were considered relevant. The questionnaire and sample interviewee list were subjected to the University Ethics approval process. All participants were informed that their views would be kept anonymous and only aggregate results would be reported. The pilot questionnaire was constructed using the literature review as a basis. This was then subjected to consultation by asking experienced individuals for input in the preliminary discussions stage or the pilot study. By incorporating the pilot study feedback more focussed and appropriately framed questions were obtained.

The key strategy used for selecting the sample was that all participants would have to come from diverse areas of the New Zealand building industry. This diversity of participants would help by providing a very generalist understanding of the issues under investigation. This is similar to what is termed as a cross section study in the field of public health or epidemiology (Olsen and StGeorge, 2004). This technique allows for choosing a stratified random sample of individuals. In other words, individuals with certain subgroup characteristics such as belonging to a particular part of an industry or a certain type of sector such as regulator, training provider etc. were selected and no particular group was overrepresented. A similar data collection approach in the New Zealand building industry was used by Hunn et al. (Hunn et al., 2002).

The interview sample was selected from both the New Zealand Construction Industry Council (CIC) website and Building Research recommendations. Individuals chosen were either experts in their field or were leaders of their organizations. 35 people were interviewed, between 1 and 2 hours duration, from industry associations/professional associations, academia, technical organisation, Government (including local and centralgovernment), unions, construction contractors, industry experts, property developers and subcontractors.

The data obtained from the fieldwork was broken down into categories and then subcategories. In other words, a taxonomicalor hierarchical 
approach to data organization was adopted. This led to the data being analysed by using the quantitative technique of descriptive statistics. From this analysis an objective view of the coded and categorised data was obtained. These outcomes were then compared and contrasted to the available literature. The software used to aid the analysis was QSR Internationals NVivo suite. NVivo uses grounded theory as a guiding principle. Here, the taxonomical approach to categorization of data in terms of themes is followed. In other words, the context of the answers helps to provide and link answers and explanations and provide richer analysis of the data. This suite was selected as it helped to categorise responses in context and with links to original quotations and documents, and has the ability to provide data models rather than numbers.

\section{THE EFFECTS OF THE 2007 VOLUNTARY LICENSING AND 2009 COMPULSORY LICENSING ON SKILLS}

By 2007 voluntary licensing will be available in New Zealand. The research aimed to see whether the licensing regime being put into place in New Zealand would require new skills when voluntary and compulsory licensing were introduced.

Out of a total response of 33, 18 participants felt that there would be changes in skills encompassed within occupations when voluntary licensing was introduced. The belief was that practitioners at the skill levels of high (designated as professionals and managers), intermediate (designated as technicians and trades) and low (designated as site workers) would increase in specialization when licensing was introduced. This would mean that job descriptions would become narrower and narrower, akin to the advent of subcontracting in building construction. There would be a move towards a more focussed skills set. Out of a total of 18, 11 participants mentioned that skills would become mom specialized. Only 1 participant felt that generalist skills would be needed.

From the construction firm perspective one can see that specialisation is already beginning to take root. A supporting comment for increased specialisation in architecture summed up the changes as: "There are definitely moves in our industry to get subsets as whole that are specialised in some areas. Take for instance architecture. We are seeing subsets forming in concept architects and back of house design architects...Under the back of house, you are a/so getting another specialist group whichis around the far;ade and water tightness type speciality and also acoustics. n

The intermediate level and high level of skills are particularly faced with the possibility of increasing specialisation in skills in the next two years. The answers point towards an increasing emphasis on specialization but having the same core set of basic skills needed to perform fundamental tasks. Essentially, the influence of occupational licensing is speeding up this process. This is because the structure being proposed points towards specialist practitioners being needed both on the design and construction side of the building industry. For instance, comments from a participant with a carpentry background suggested that "Carpentry schools in the old days used to encompass a whole range of disciplines. As we grow and a building becomes more advanced, technology and buildings become more systemized we're going to have specialist areas so I suggest our training in the future will be more specific and in disciplines that are more specializedn.

The effects of licensing were seen to be in line with the Ministry of Economic Development (MED, 2003a) assessment of better skilled practitioners. The word best used to describe it would be that of "professionalism". That is, licensing would be the defining factor in raising the esteem of practitioners themselves and their own standing in society. Licensing would ensure a minimum threshold of competency is fulfilled. Increasing Professionalism due to licensing was found to be the common theme amongst the participants.

One issue of concern, raised by about a quarter (8/33) of participants was that occupational licensing would increase skills shortages which in tum would restrict any new skills or change in diiection of skills. Foi instance, one part;cipant noted that, "There are trades and professions and areas where there is already a serious shortage of workers even now despite the willingness of employers to take on semi-skilled labour to do the work. It could be exacerbated by licensing."

2009 (recently changed to 2011) is the year designated by the New Zealand Department of

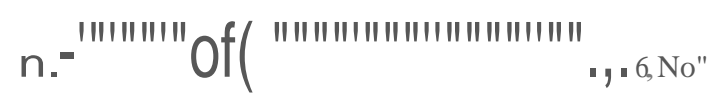


Building and Housing as the time by which all identified practitioners will have to be licensed to work in the industry. The participants were asked whether, with compulsory licensing, they believed they would need new types of skills. A majority of participants felt that there would be changes in skills by this stage. The most significant change would an attempt to decrease the labour input by increasing prefabrication and off site mechanised construction.

For example, a typical comment was, "So what you're going to see in construction will be an attempt to reduce the labour input both on site and in materials supply to site. So my expectation is that you'll see far more off site house building. And with it you'll see a whole different set of skills being brought into factories and you'll get far less site specific skills."

With the increase in prefabrication and off site construction, new skills would be required. The trend was a mixture of both types of skills (generalist and specialist) in order to facilitate and increase the penetration of prefabrication and the simplification of the building process by requiring specialist off site and generalists with systems thinking skills on site for assembly of parts of the structure. Concern was evident on how the industry would be able to find the people required. "All of a sudden you will have a percentage of the people that are sort of semiskilled not being able to do any work and as it is at the moment we can't get enough people out there to work in the construction industry. We are struggling now to get enough people, a percentage of them are under skilled, you take those away, it's going to create a huge gap there."

The exodus of semi skilled practitioners due to licensing, the ageing of the current practitioner workforce who would be retiring and the lack of new entrants into the industry due to increased competition from other industries were seen to be key drivers for efficiency gains in the building industry and changes in skills requirements. Expectations were that licensing would exercise a severe capacity constraint on the existing workforce by limiting the number of new entrants and increasing temporarily the loss of retiring participants uninterested in becoming licensed. These skills shortages would be one of the factors which would limit a change in the skill's balance of generalist and specialist practitioners. However, this is against an identified trend for both, and new, types of practitioner (generalist and specialist) being needed due to the apparent increasing market penetration of prefabrication; specifically, more generalist practitioners on site and more specialist practitioners involved in off site construction.

\section{DISCUSSION: THE EFFECTS OF LICENSING ON FUTURE SKILLS}

Occupational licensing could be seen to have three effects in the context of skills needs. Two of these effects are clearly pointed out in the literature from other industries, and countries, which have licensed professionals. The first being improved quality of service through improved skills and restrictive entry and the second an increase in skills shortages. These effects are confirmed in this research which shows an expected increasing professionalism in the New Zealand building industry after licensing is introduced. The results of this research also agree that the licensing regime would exacerbate skills shortages in New Zealand. From 2010, the exodus of semi skilled practitioners not intending to gain licensing, retiring practitioners, and the lack of new entrants into the industry would compound the already existing skills shortage situation.

The results extend the literature on the effect of licensing into a third area - that of future skills needs. The observation that the way an occupational licensing regime is structured (in the form of specialist license classes) has an effect on the change in direction of skills towards increasing specialisation is shown in this research. Had the license classes been structured to allow increasing amounts of flexibility, that is, for example, a generalist license for a construction contractor, then that would mean that multi-skilling in trades \{Clarke and Wall, 1998) or trans-disciplinary professionals (Wilkinson and Scofield, 1998; Chan et.al., 2001) would have been the direction of skils changes. By restricting the license to specialist categories and requiring a qualification for new entrants, licensing dissuades dual trades. Higher registration and license maintenance costs could mean that more than one license may not be seen as beneficial by new entrants. Multi-skilling could have alleviated some of the shortages caused by ageing of the construction workforce (Haig, 2004) and lack of new entrants (Dol,2006). 
From the results of this research, it can be seen that New Zealand will require an increase in the number of specialist and generalist practitioners where technology was seen to be the main driver of this trend and licensing as a driver of skills was seen to significantly influence this trend. Ultimately, the results suggest that for New Zealand, the effects of licensing means increasing skills shortage coupled with more advanced technology which would see the increased use of offsite or prefabricated components leading to a new mix of specialist and generalist practitioners.

\section{CONCLUSIONS: THE INFLUENCE OF OCCUPATIONAL LICENSING AND SKILLS SHORTAGES ON FUTURE SKILLS NEEDS}

New Zealand introduced occupational licensing as a way of protecting the public from building industry failures of standards and quality. Occupational licensing is beneficial to the New Zealand building industry in that it will lead to an increase in professionalism and improved standards of work. Whilst previous studies have found that quality of service improves in terms of better and more professional service proportional to the intensity of licensing no parallels exist in the literature for licensing leading to skills becoming more specialized or changing as a result of the way in which licensing is inherently structured. This research shows that in New Zealand, licensing will cause existing skills shortages to worsen. Specifically licensing would lead to existing skills shortages persisting due to the new implementation of an occupational licensing regime during the years 2007-2010. The impact on the building industry will be to force a change in the working practices, increasing the move to offsite prefabrication and change the types of skills the industry requires.

\section{ACKNOWLEDGEMENTS}

The authors would like to thank Building Research for funding this research and Dr. john Duncan from Building Research for his support during this research.

\section{REFERENCES}

Arkani, S., Clarke, L., and Michielsens, E. (2003). Regulation for Survival: training and skills in the construction labour market in Jersey, Channel Islands. Journal of Vocational Education and Training, 55(3), 261-280

Building Act (2004). Public Act 2004, No 72, Date of assent -24 August 2004, New Zealand Department of Building and Housing, Available from www.building.govt.nz, Accessed on 18 March 2005.

Building Control Commission (2003). Review of the categories and classes of building practitioner registration in Victoria, Industry Discussion Paper, 30 September 2003, Building Commission \& Building Advisory Council, Victoria, Available at www.buildingcommission.com.au, Accessed on 10 January 2006.

Building Control Commission (2005).

Competencies, Building Commission \& Building Advisory Council, Victoria, Available online at www.buildingcommission.com.au, Accessed on 10 January 2006

Carroll, S. L., and Gaston Robert

J.(1983).0ccupational Licensing and the Quality of Service :An Overview, Law and Human Behaviour, Vol 7,No.2/3, Professional Regulation (Sep.1983).

Chan, E. H. W., Chan, M. W., and Chan, A. T. H. (2001). Disintegrating professional boundaries: a case with the building professions in Hong Kong. International Journal of Project Management, 19(2), 127-135

CIC (2005).The Built Environment Research Strategy, New Zealand Construction Industry Council, Available online at www.nzcic.co.nz, Accessed on 20 December 2005,pp 11.

Clarke, L., and Wall, C. (1998). A blueprint for change: Construction skills training in Britain. Bristol, The Policy Press: 15-18.

DoBH (2004).Licensing of Building Practitioners: Discussing the Options: August 2004. New Zealand Department of Building and Housing, Wellington, Available online at www.dbh.govt.nz, Accessed on 10 January 2006. 
DoBH (2005). Paper 1:Background to licensing ,objectives of licensing and implementation timetable, Expert Consultation Group Workshop, Proposed License Classes for the Building Industry, Feb 2005, New Zealand Department of Building and Housing, Wellington ,made available by a source at the Department.

DoBH \{2005a), Paper 4: How do we make it work\{implementation implications), Expert Consultation Group Workshop, Feb 2005, New Zealand Department of Building and Housing, Wellington ,Available online at www.dbh.govt.nz, made available by a source at the Department.

DoBH (2005b).Licensing of Building Practitioners: Feedback from consultation and final proposed licence classes: March 2005. New Zealand Department of Building and Housing, Wellington, Available online at www.dbh.govt.nz, Accessed on 15 January 2006.

DoBH (2006).What is occupational licensing, New Zealand Department of Building and Housing, Wellington, Available at http://www.dbh.govt.nz/. Accessed on 11 August 2006

DoBH (2006a).When licensing applies, New Zealand Department of Building and Housing, Wellington , Available at http://www .dbh.govt.nz/, Accessed on 11 August 2006

Do(2004). Construction Industry Workforce Trends, Work-Insight Paper, Issue 5, November 2004, New Zealand Department of Labour, Available online at www.dol.govt.nz ,pp 32-34, Accessed on 18 Feb 2005.

Do(2005). Wage Growth- September 2005, New Zealand Department of Labour, Available at: www.dol.govt.nz, Accessed on 9 December 2005.

Do(2006). Skills shortages in the trades-the 2005 picture,June 2006, New Zealand Department of Labour, Available online at www.dol.govt.nz ,Accessed on 11 August 2006.

Georgiou, J., Love, P., Smith, J. (1999). Builder Registration in Victoria, Australia-A Sign of
Things to come .2nd International Conference on Construction Industry Development, and 1st Conference of CIB TG 29 on Construction in Developing Countries 27-29 October 1999, The Pan Pacific, Singapore

Georgiou, J., Love, P., Smith, J. (2000). A review of builder registration in Victoria, Australia. Structural Survey, 18(1), 38-45.

Glaser., G.B. and Strauss, A. L. (1967). The discovery of grounded theory: strategies for qualitative research. Chicago:Aldine.

Glaser., G. B. (1992).Basics of grounded theory analysis: emergence vs. forcing. Mill Valley, Ca.: Sociology Press.

Haig, R. (2004). Age Trends in the New Zealand and Australian Trades Workforce 1991-2001.

Labour, employment and work in New Zealand: Proceedings of the Eleventh Conference, Industrial Relations Centre, Victoria Management School, Vi ctoria University of Wellington., Sourced from a confidential source at the New Zealand Department of Labour.

Kleiner, M. M. (Fall 2000) Occupational Licensing. Journal Of Economic Perspectives, 14(4), 189-202.

MED (2003). Discussion Document: Better Regulation of the Building Industry in New Zealand: Discussing the Options, New Zealand Ministry of Economic Development, Available at www.med.govt.nz, Accessed on 9 January 2006

MED (2003a).Socialand Economic Impact Study of Changes to Building Regulation, A study by PricewaterhouseCoopers for the New Zealand Ministry of Economic Development, Available at www.med.govt.nz, Accessed on 15 January 2006.

Naoum, S.G. (1998).Dissertation Research and Writing for Construction Students. Butterworth Heineman. 
NZIER (2004). About NZIER, New Zealand Institute of Economic Research, Available at www.nzier.org.nz , Accessed on 9 March 2005.

NZIER (2004a).Quarterly Survey of Business Opinion, October 2004, New Zealand Institute of Economic Research, Available at www.nzier.org.nz, Accessed on 9 March 2005.

NZIER (2005).Quarterly Survey of Business Opinion, January 2005, New Zealand Institute of Economic Research, Available at www.nzier.org.nz, Accessed on 9 June 2005.

Olsen, C., and StGeorge, M.D. (2004). Cross Section Study Design and Data Analysis, The Young Epidemiology Scholars program, College Entrance Examination Board, Available at www . collegeboard. com ,Accessed on 10 January 2006.

Perfoff, J., M. (1980).The Impact of Licensing Laws on Wage Changes in the Construction Industry. Journal of Law and Economics, Vol.23, No.2 (Oct., 1980), 409-428.

Rottenberg, S. (1980). Introduction, in Occupational Licensure and Regulation. S. Rottenberg, ed. Washington, American Enterprise Institute, pp.1-10.

Wilkinson, S., and Scofield, R.(1997).1ntegrating architecture and engineering education: A case study of a new management course .Proc.3rd and 4th Int. Electronic AUBEA Conf.19971998, Australia,Australian Universities Building Education Association-Research, Australia, pp 37-40.

Zikmund, W. (1997). Business Research Methods. Dryden Press.

Zhou, X. (1993). Occupational Power, State Capacities, and the Diffusion of Licensing in the American States: 1890 to 1950, American Sociological Review, 58(4), pp 536-552. 